\title{
FREEDOM IN THE ARCHIVE: On Doing Philosophy through Historiography
}

\author{
RÉAL FILLION \\ University of Sudbury, Canada
}

\begin{abstract}
It is argued in this article that Foucault's most distinctive contribution to philosophical practice is to be found in his distinctive mode of taking up historiography, exploring critically the conditions and limits of knowledge through archival work. The focus on knowledge would seem to place him in the critical lineage of Kant; however, his appeal to history and archival explorations reconfigure the relation between sensibility and the understanding in a way that suggests a different concern with the conditions of "a possible knowledge." After discussing how Foucault's archival work engages a distinct sensibility, I suggest that his concern with knowledge can best be understood not within a transcendental project, however historicized, but within the logical space of Hegel's Doctrine of the Concept, specifically the discussion of the Idea of cognition where it is a question of the twin processes of unifying subjectivity and objectivity as expressive of cognition's "urge to truth." Understood within this conceptual context, Foucault's distinctive archival approach to what he calls "subjectivation" and "objectivation" allows us to appreciate the distinction between knowledge and truth in a way that leaves open the possibility of transformation.
\end{abstract}

Keywords: history, archive, sensibility, knowledge, conditions, subjectivity, objectivity, possibility, cognition, Idea, truth.

Alain Badiou, in a lecture titled "The Adventure of French Philosophy," notes that there are historically charged "moments" of philosophical thinking (between Parmenides and Aristotle and between Kant and Hegel, for example), particular times and places that capture something like "a universal aim of reason" in the distinct terms of that period. He then defends the idea that there was "a French philosophical moment of the second half 
of the twentieth century which, everything else being equal, bears comparison to the examples of classical Greece and enlightenment Germany."1 In a more historical vein, Stefanos Geroulanos has recently presented the distinctiveness of post-war French thought as a critique of the ideal of "transparency" (both in terms of the relation to one's self as knowing subject, and in terms of knowing the world) that "involved major attempts to overcome the limitations and violence of modernity and to remold thought and society dramatically and swiftly." 2 Foucault was a central figure for both authors, insofar as his work takes up and challenges the "aim" of such a purported "universal reason" as well as the notion of a subject transparent to itself in its knowing efforts.

What distinguishes Foucault's distinct philosophical contribution within this philosophical "moment" is that a good part of his own philosophical practice involved not the writing of treatises or extended arguments, but the writing of histories that, like the histories written by historians, involved archival work. That is, his theorizing efforts deployed themselves within distinctly historical and historiographical investigations. This philosophical practice has over the years raised questions about his status as either a philosopher or an historian, ${ }^{3}$ engaging Foucault himself in debates with historians, ${ }^{4}$ and in fact continues to engage practicing historians. ${ }^{5}$ And, in fact, Foucault was himself quite coy about explicitly identifying his work as philosophical, at least until his turn to questions of the self in what turned out to be his final years, ${ }^{6}$ and even then deciding to give one account of his philosophical contribution under the pseudonym of Maurice Florence. ${ }^{7}$ This particular account will be important for what follows because it places his overall philosophical work in the context of what he calls modes of "subjectivation" and modes of "objectivation." By means of this text, I will argue that we can better understand the philosophical character of Foucault's work not by insisting on a Kantian filiation, but by turning to Hegel's Science of Logic, where the twin processes of determining subjectivity and objectivity are taken up in the Idea of cognition. In doing this, I am not claiming that

\footnotetext{
${ }^{1}$ Alain Badiou, The Adventure of French Philosophy (2012), li.

${ }^{2}$ Stefanos Geroulanos, Transparency in Postwar France: A Critical History of the Present (2017), 21.

${ }^{3}$ Béatrice Han-Pile, "Is early Foucault a Historian? History, history and the analytic of finitude," Philosophy $\mathcal{E}$ Social Criticism 31:5-6 (2005), 585-608. Although concerned with Foucault's "archaeology" more specifically, Han-Pile's reading of it as "designed as a way to keep the idea of a transcendental critique alive by historicizing it while invalidating its anthropocentric premises and conclusions" (604) is relevant to my argument here, in that I suggest that we can better appreciate this paradoxical attempt to historicize a transcendental critique by situating Foucault's efforts within Hegel's philosophical framework rather than insist on Kant's.

${ }^{4}$ See in particular Michelle Perrot (ed.) L'impossible prison: Recherches sur le système pénitentiaire au XIXe siècle (1980). For an interesting discussion of the reception of Foucault by historians during his lifetime, see Allen Megill, "The Reception of Foucault by Historians." Journal of the History of Ideas 48:1 (1987). 117-141. On Foucault's importance for history and historiography, see Paul Veyne, "Foucault Revolutionizes History," in Foucault and his Interlocutors, ed. Arnold Davidson (1997).

${ }^{5}$ See for example Damien Boquet, Blaise Dufal, Pauline Labey (eds.) Une histoire au présent: Les historiens et Michel Foucault (2013).

${ }^{6}$ See Christopher Falzon and Timothy O'Leary, "Introduction: Foucault's Philosophy," Foucault and Philosophy, eds. Timothy O'Leary and Christopher Falzon (2010).

7 Michel Foucault, "Foucault," in Aesthetics, Method, and Epistemology: Essential Works of Foucault 1954-1984, Volume 2, ed. James D. Faubion (1998), 459-463.
} 
Foucault himself made use of Hegel's categorial approach to conceptual determination, but rather that his work is illuminated by it. Having said that, Foucault was quite aware that his work was in an uneasy relation to Hegel. If he shared with some of his contemporaries (Deleuze, Derrida) a desire to detach himself from a reigning Hegeliansim, ${ }^{8}$ he also declared in his inaugural lecture at the Collège de France, taking up his Chair in the History of Systems of Thought, ${ }^{9}$ that such detachment "assumes that we are aware of the extent to which Hegel, insidiously perhaps, is close to us; it implies a knowledge, in that which permits us to think against Hegel, of that which remains Hegelian." 10 I take this comment to be especially perspicuous, not only for understanding Foucault's work, but also for appreciating the continuing relevance of certain features of Hegel's project too summarily dismissed by those wishing to make use of the kinds of insights that Foucault's work provides. ${ }^{11}$

But before engaging these more strictly philosophical considerations, I want first to examine a little more closely Foucault's early turn to historiography and archival work as the more appropriate place to express his concerns and distinct sensibility.

\section{Foucault and the Archive}

Foucault definitely wrote histories: ${ }^{12}$ a history of madness, a history of the "birth" of the clinic and another of the "birth" of the prison, a projected multi-volume history of sexuality (of which three volumes were published, two shortly before his death). ${ }^{13}$ One might then be tempted to situate his work as belonging to the explosive creativity of la nouvelle histoire that sought to explore, beyond the traditional focus on l'histoire événementielle, new problems, new approaches, and new objects, to use the terms used by Jacques Le Goff and Pierre Nora in the three volumes of their Faire de l'histoire. ${ }^{14}$ And yet as eclectic as the group of historians that formed part of such a new history was, Foucault's work still stands apart, perhaps as works of history, but not of an historian. Foucault himself, though

\footnotetext{
${ }^{8}$ For a good discussion, see Bruce Baugh, French Hegel: From Surrealism to Postmodernism (2003). See also Holden Kelm, «With Hegel Against Hegel?: Strategic and Methodological Implications of Foucault's AntiHegelianism » Hegel-Jahrbuch 2015:1, 323-328.

${ }^{9}$ Replacing Jean Hyppolite's Chair of the History of Philosophical Thought. The replacement of "philosophical" with "systems of" thought speaks to Foucault's indebtedness to (but also difference from) Hyppolite, which he is recognizing in this inaugural lecture. For the relation of Foucault to Hyppolite, see Didier Eribon's biography Michel Foucault, (1991), especially Chapter 2, “The Voice of Hegel." Also, Leonard Lawlor, Thinking Through French Philosophy: The Being of the Question (2003). I also discuss this relation in my "Foucault after Hyppolite: Toward an A-theistic Theodicy," The Southern Journal of Philosophy, 43:1 (2005), 79-93.

${ }^{10}$ Michel Foucault, "The Discourse on Language" in The Archaeology of Knowledge, (1976), 235.

${ }^{11}$ For a good discussion on this point, see James Muldoon, "Foucault's Forgotten Hegelianism," Parrhesia 21 (2014), 102-112.

12 The focus here is on what Foucault himself decided to publish. The appeal to history and historiography is also very present in his lectures at the Collège de France, which now have all been published, and these lectures are also a rich source for exploring Foucault's distinctive practice of engaging philosophical questions through historiography.

${ }^{13}$ A fourth, Michel Foucault, Les aveux de la chair (2018), was announced as "forthcoming" back in 1984 but has only recently appeared.

${ }^{14}$ Jacques Le Goff and Pierre Nora, Faire de l'histoire (1974).
} 
admitting to making use of the "most conventional methods: demonstration or, at any rate, proof in historical matters, textual references, citation of authorities, drawing connections between texts and facts, suggesting schemes of intelligibility, offering different types of explanation," sometimes characterizes them as "fictions." ${ }^{15}$ In doing so, he is of course distancing himself from the discipline of history, which, despite its interest in and use of narrative, continues to claim for itself a kind of knowledge. And it is precisely the relation to knowledge that Foucault wishes to interrogate philosophically through his historical investigations.

In light of this, it might be useful to distinguish, as does Arlette Farge, an historian who eventually collaborated with Foucault (at his request), ${ }^{16}$ between the engagement with documentary sources, on the one hand, and the "mise en récit" or the putting into narrative of that work on the other, between historical research and the presentation of that research through historical writing. The latter she says is guided by a "principle of authority", thereby assuming a kind of power (presumably with reference to the reader) embodied in the historian's commitment to writing what is true or truthful. She notes, however, that within this task, this "mise en récit," which is meant "to enable knowing, to enable understanding, but also to enable feeling," the following concern about the distinction between the research itself and the writing that follows it:

Despite all of this, one might straightaway be left wondering: that which was eliminated from the sources and from the choice of hypotheses is rarely acknowledged. Yet, this "rejected" remainder, these "discards" stemming from the research could no doubt in themselves be the object of interrogations, even sustained work. History thereby remains secretive about its research protocols, and I for one count myself among those who regret it. ${ }^{17}$

I think the distinction between historical research itself and the "mise en récit" of historical writing can help us better appreciate Foucault's philosophical practice of historiography, a writing of history that does not seek to place itself under the "principle of authority" of the historian's commitment to a truthfulness that involves basic forms of documentary exclusion and the relation to the reader thereby presupposed. On the contrary, it is truth and truthfulness themselves that come under historical and historiographical scrutiny, engaging Foucault in a distinct kind of historical writing.

Another way to put this is to consider the manner in which R.G. Collingwood, like Foucault a thinker straddling both philosophy and history, distinguishes, in his An Essay on Philosophical Method, historical writing from philosophical writing in the following way: because the knowledge which historical writing attempts to communicate is selective and therefore necessarily incomplete, it is always focused on "some central nucleus of knowledge" surrounded by "a penumbra of uncertainty," with the result that the "division

\footnotetext{
${ }^{15}$ Michel Foucault, Power: Essential Works of Foucault 1954-1984, Volume 3 (2000), 242.

${ }^{16}$ Arlette Farge and Michel Foucault, Disorderly Families: Infamous Letters from the Bastille Archives, ed. Nancy Luxon (2016). For a brief account of this collaboration, see Arlette Farge, "Travailler avec Michel Foucault," Le débat, 41:4 (1986), 164-167.

${ }^{17}$ Arlette Farge, "Écrire l'histoire," Hypothèses 7:1 (2004), 317-318. My translation.
} 
of what we know into what we know for certain and what we know in a doubtful or problematic way, the first being narrated and the second suppressed, gives every historical writer an air of knowing more than he says, and addressing himself to a reader who knows less than he". ${ }^{18}$ In contrast, according to Collingwood, philosophical writing does not primarily address a reader distinct from the author; and the purpose of writing "is not to select from among his thoughts those of which he is certain and to express those, but the very opposite: to fasten upon the difficulties and obscurities in which he finds himself involved, and try, if not to solve or remove them, at least to understand them better."19

I think Collingwood's distinction here throws light on Foucault's particular mode of philosophizing through writing history, of appealing to historical sources. His explorations of madness, criminality and delinquency, abnormality and sexuality through his histories are not focused on articulating what we can be said to know about these things - and thereby suppressing what is uncertain - but rather they are focused on those very "difficulties and obscurities" their continuing presence poses to us, despite what is claimed to be known about them. Working through these "difficulties and obscurities" for Foucault is explicitly a work of transformation, for himself first of all, but also, insofar as he chooses to write, for the reader. His works do remain works of history (as distinct from fiction and literature grounded in, and guided by, an author's imaginative project, whatever use might be made of historical archives) inasmuch as Foucault recognizes and accepts that what he says in them "can be verified or invalidated in the same way as any other book of history"20; but the problem he sets for himself "is not to satisfy professional historians; my problem is to construct myself, and to invite others to share an experience of what we are, not only our past but also our present, an experience of our modernity in such a way that we might come out of it transformed." 21

This appeal to the transformation of "what we are" through an appeal to history situates Foucault's work squarely within the second half of the twentieth-century. Born in 1926, Foucault was an adolescent during the war and the occupation of France, witnessing them from the limitations imposed by his age. ${ }^{22}$ As a young adult he needed to make his way in and attempt to come to terms with various movements explicitly appealing to a sense of History. For example, the French Communist Party wielded considerable influence after the war, given the important role that French Communists played in the Resistance, and as the historian Maurice Agulhon recounts in an interesting book of "self-histories"

\footnotetext{
18 R.G. Collingwood, An Essay on Philosophical Method (1936), 208-209.

19 Ibid.

${ }^{20}$ Foucault, Power, 242.

${ }^{21}$ Ibid.

${ }^{22}$ Both Geroulanos, Transparency in Postwar France, 153, and Eribon, Michel Foucault cite a passage from a late interview (1983) where Foucault evokes the time before and during the war: « Much more than the activities of family life, it was these events concerning the world which is the substance of our memory. I say " our » because I am nearly sure that most boys and girls in France at this moment had this same experience. Our private life was really threatened. Maybe that is the reason why I am fascinated by history and the relationship between personal experience and those events of which we are a part. I think that is the nucleus of my theoretical desires. »Quoted in Michel Foucault, p. 10.
} 
solicited by Pierre Nora ${ }^{23}$ from a number historians, many from Foucault's generation, following the Libération, there was a social, national and revolutionary effervescence filled with optimism and hope that attracted many to a more political engagement with the Left. ${ }^{24}$

Indeed, Foucault himself, at the behest of his friend and mentor Louis Althusser, joined the French Communist Party in 1950. He left it a few years later, having never showed much enthusiasm for its practices, but it is interesting to note that his first book, a commissioned work called Mental Illness and Personality published in 1954, made considerable use of the Marxian notion of alienation, and even concluded with a chapter on Pavlov. However, Foucault was later to revise the book, retitling it Mental Illness and Psychology, 25 which included substantial revisions of the second part and the elimination of the chapter on Pavlov. And in fact, Foucault continued to distance himself from this early work, no longer authorizing reprints after 1966, and even attempting to prevent publication of the English translation. ${ }^{26}$ As David Macey, one of his biographers suggests, as far as Foucault was concerned, his first book was not this one, but rather Histoire de la folie. ${ }^{27}$ Following upon this idea, I would suggest that what lies between these two "first" books is the turn to a historiographical mode of philosophizing cemented in his experience of the archive.

We might read Foucault's relation to his own work here as an attempt to speak in his own voice (instead of having it merely reflect the predominant sense of History), but precisely by ceding his voice to the history discovered in his own working of the archive as he pursued his investigations as transformative experiences (as distinct from the scholarly "pursuit of knowledge"). If "mental illness" is the institutional term for how, at a given time (the present), some of us (medical and para-medical professionals and other professionals in various agencies, psychological researchers) deal with others whose comportment is problematic in certain discursively defined ways, its unquestioned use is challenged in a distinct way when contrasted with a history that reveals distinctly different practices at other times. ${ }^{28}$ Foucault's engagement with the writing of history is an exploration of such distinctive contrasts, with a specific focus on seventeenth and eighteenth century practices in Europe. Identifying this period as the Classical Age, sometimes translated into English as the Age of Reason, speaks directly to what is, ultimately, Foucault's philosophical concern with these changing ensembles of practices undergirding the broad, Enlightenment-inspired appeal to reason as it confronted various forms of unruliness, and this philosophical concern, as noted above, is with the possibility of transformation. Might we not see in this concern with transformation, not the revolutionary transfor-

\footnotetext{
${ }^{23}$ Pierre Nora, ed. Essais d'ego-histoire (1987), 20-21

24 See as well Transparency in Postwar France.

${ }^{25}$ Michel Foucault, Mental Illness and Psychology (1987).

${ }^{26}$ David Macey, The Lives of Michel Foucault (1993), 64.

${ }^{27}$ Michel Foucault, Histoire de la folie (1972). The same point is made by Didier Eribon Michel Foucault, 70.

${ }^{28}$ This is part of the significance of Foucault's approach: because his historical approach does not make continuist assumptions about the evolution of the knowledge undergirding the practices he is examining, their distinctiveness comes into sharper focus and has a greater impact on our sensibility.
}

Foucault Studies, No. 25, 103-119. 
mation heralded by many at the time, but in effect its own transformation of the appreciation of, and appeal to, history? But here not History understood theoretically and abstractly, but history encountered within the archive. ${ }^{29}$

Foucault once declared to a group of historians: “My books aren't treatises in philosophy or studies of history; at most, they are philosophical fragments put to work in an historical field of problems." 30 This reference to philosophical "fragments" should I think be understood in two ways. First as a rejection of philosophical work as issuing into systems of thought (principally Hegelian and Marxian at the time). But also as an approach to philosophical questioning that allows itself to be guided by a certain sensibility. William E. Connolly talks about Foucault's distinctive philosophical approach as exhibiting a particular ethical sensibility and quotes the following passage from Foucault:

We have to dig deeply to show how things have been historically contingent, for such and such a reason, intelligible but not necessary. We must make the intelligible appear against a background of emptiness, and deny its necessity. We must think that what exists is far from filling all possible spaces. ${ }^{31}$

The basic point I would like to underscore is that it was Foucault's experience within the archive $^{32}$ that allowed him to articulate this sensibility to his intellectual concerns, thereby throwing new light on various struggles in his (and our) times. This is the important point: Foucault's histories and historiographical practices are less driven by an interest in the knowledge that can be achieved of the past, with the assumption that this will somehow be relevant to and illuminate the present, than it is by a desire to challenge the terms and constraints that govern the present by having it confront its own archive.

By archive, here, I mean what historians usually mean by the term (specific repositories of recorded documents) but I also have in mind Foucault's discussion in his Archaeology of Knowledge, where in the introductory chapter he contextualizes his concerns with work being done by the new historians, about how the archive for historians is not merely a repository of things said and done in the past but, "one way in which a society recognizes and develops a mass of documentation with which it is inextricably linked."33 But further, the importance of the archive for thinking about how to challenge existing constraints follows from recognizing how what we say and do in the present is also caught up in that

\footnotetext{
${ }^{29}$ Here, of course, Foucault remains closer to historians than to theorists of history and philosophers, as it were, but with the caveat stated above about the distinction between use of the archive and the «mise en récit » that historians take away from it. For a discussion of the historian's experience of the archive relevant to Foucault, see Arlette Farge, The Allure of the Archives, (2013).

${ }^{30}$ Michel Foucault, Power, 224.

${ }^{31}$ Foucault, "Friendship as a Way of Life," quoted in Connolly, "Beyond Good and Evil: The Ethical Sensibility of Michel Foucault," Political Theory, 21:3 (1993), 367.

${ }^{32}$ And arguably it is the archive, or collection, housed at the Carolina Rediviva University Library at Uppsala, Sweden, where Foucault wrote History of Madness (2006) that allowed him to turn from the trajectory of his studies in psychology to his own philosophically inflected form of historiography.

${ }^{33}$ Michel Foucault, The Archaeology of Knowledge and the Discourse on Language (1972), 7.
} 
archive. $^{34}$ As he puts the point later on: "it is not possible for us to describe our own archive, since it is from within these rules that we speak... [it] cannot be described in its totality; and in its presence it is unavoidable. It emerges in fragments, regions, and levels..."35 But herein lies its promise if approached as an historical field of problems. Foucault writes: "at once close to us, and different from our present existence, it is the border of time that surrounds our presence, which overhangs it, and which indicates it in its otherness; it is that which, outside ourselves, delimits us."36 Engaging this archive, for Foucault, can serve this contrastive function and his historiographical practice should be seen as diagnostic, ${ }^{37}$ as opposed to being largely epistemologically defined; it engages history not primarily in terms of knowing the past, but as a way of addressing problematic features of the present (like the treatment of those considered mad, criminal, deviant).

And what further distinguishes Foucault's approach and working of the archive is that those problematic features are not first identified and defined theoretically, but are rather quite simply felt. ${ }^{38}$ Again, the reference to the role played by Foucault's own sensibility is crucial here. Probably the best text to exhibit this sensibility is "Lives of Infamous Men."39 This text was to serve as an introduction to a projected series of texts called Parallel Lives, which were meant to present the reader directly with lives encountered within the archive by showcasing the archives themselves, the brief documentary evidence of those lives otherwise promised historical oblivion, illuminated, as Foucault puts it, by a "beam of light," 40 which he describes as follows: "What snatched them from the darkness in which they could, perhaps should, have remained was the encounter with power; without that collision, it's very unlikely that any word would be there to recall their fleeting trajectory." 41 Foucault cites only two archival examples in this text. Here is the second:

\footnotetext{
${ }^{34}$ For a fascinating discussion of the notion of the "archive" as a space of "domiciliation" and "consignation" asserting a problematic authority over access to the past and to the future, see Jacques Derrida's Archive Fever: A Freudian Impression (1996).

${ }^{35}$ Michel Foucault, The Archaeology of Knowledge, 130.

${ }^{36} \mathrm{Ibid}$.

${ }^{37}$ For Foucault "the archive deploys its possibilities (and the mastery of its possibilities) on the basis of the very discourses that have just ceased to be ours; its threshold of existence is established by the discontinuity that separates us from what we can no longer say, and from that which falls / outside our discursive practice; it begins with the outside of our own language (langage); its locus is the gap between our own discursive practices. In this sense, it is valid for our diagnosis." Ibid., 130-131.

${ }^{38}$ This dimension of the archive is captured quite well in Knut Ove Eliassen's "The Archives of Michel Foucault" in The Archive in Motion: New Conceptions of the Archive in Contemporary Thought (2010), where he distinguishes distinct ways that the concept of archive is taken up: the distinct sense Foucault develops in his $\mathrm{Ar}$ chaeology of Knowledge discussed above; its institutional space, and as a kind of « other » space for experiment and experience, as suggested by Foucault's notion of « heterotopias »; cf. Foucault, "Des espaces autres," Dits et écrits IV (1994),752-762.

${ }^{39}$ Foucault, Power, 157-175.

40 Foucault, Power, 161.

${ }^{41}$ Ibid.
} 
Jean Antoine Touzard, placed in the castle of Bicêtre, 21 April 1701: "Seditious apostate friar, capable of the greatest crimes, sodomite, atheist if that were possible; this individual is a veritable monster of abomination whom it would be better to stifle than to leave at large." 42

Such lettres de cachet, ${ }^{43}$ petitions from family members and other familiars to the king to incarcerate given individuals during the Classical Age, in the very language in which they were archived, illuminate the specificity of the workings of power, whereby the forcefulness of their contingent formation is actually felt by the reader with a directness that produces as its effect a kind of unsettling within the usual understanding of the basic orderings that configure the reader's sense of the world. The direct presentation of the archival material itself - that is, a presentation not framed by a discursive contextualizing narrative - directly impacts our own sensibility and reconfigures its relation to our (usual) understanding of how power operates.

Of the projected series of Parallel Lives, Foucault did publish the memoir of Herculine Barbin (1838-1868) in 1978,44 whose hermaphroditism is described in appended documents (medical examinations while she was living; studies of the autopsy after his suicide) and, here too, one's reading (and one's sensibility) is ultimately impacted by what I am suggesting is the distinct sensibility that decided the juxtaposition of the archival texts. One first reads the personal memoir composed by Barbin, which speaks of the transformations of her body at puberty and the concern this raises within the institutions that house her, leading to her sexual reassignment as male; this is followed by the archival material of the medical reports themselves; these are then juxtaposed with press reports of Barbin's suicide. The juxtaposition of the texts, and the complete absence of commentary by Foucault, ${ }^{45}$ which include the prose of a troubled existence, the detached but sharp interest of the medical examination reports, and the self-satisfied conclusions regarded the "true" sex of the autopsy reports (resting on the identification of testicular gonadal tissue) arguably has a transformative effect on the reader as the significance of the question of the contingency of sexual identity and orientation is raised in a way that more theoretical treatments can only hope for. Through this mode of engaging our archive, Foucault succeeds in impacting our sensibility to the question of sexual identity in a way that loosens the categorical grip of our present understanding of it.

\section{Foucault through Hegel rather than Kant}

What I would like to do now is explore further the philosophical significance of this archival work of unsettling our understanding of the present through its impact on our sen-

\footnotetext{
42 Ibid., 158.

${ }^{43}$ Arlette Farge and Michel Foucault, Disorderly Families: Infamous Letters from the Bastille Archives (2016).

${ }^{44}$ Michel Foucault, Herculine Barbin dite Alexina B. (1978).

${ }^{45}$ At least the edition published by Gallimard (1978) and my claim about the distinct impact is connected to this text. The English translation, Michel Foucault, Herculine Barbin: Being the Recently Discovered Memoirs of a Nineteenth Century French Hermaphrodite (1980) does contain an introduction by Foucault.
} 
sibility. One can obviously see in this formulation a reference to the Kantian critical project of determining the conditions of possibility and limits of knowledge, and one can see echoes of that project in Foucault's work. But unlike Béatrice Han's ${ }^{46}$ treatment of this question, my focus is on the archival work and not on what might be deemed Foucault's own (failed, on Han's estimation) critical project inasmuch as it situates itself "between the transcendental and the historical" (the subtitle of Han's work). While Foucault's exploratory assessment and determination of his own early archival work as "archaeological" might reflect transcendental concerns and difficulties, the actual historical works put the play of sensibility and the understanding into their own distinct context that I believe to be thoroughly historical and reflective of a fundamentally alternative approach to philosophy, one that eschews the kind of universality that is a principal preoccupation of transcendental approaches. In this I agree with John McCumber ${ }^{47}$ and his parsing of philosophy with the somewhat radical distinction between what he calls a "traditional" philosophical approach that remains committed to articulating a "timeless truth" (via various atemporal notions and concerns) and one that abandons this quest in favor of exploring the temporality of our efforts to make sense of things, which McCumber calls the "continental alternative." To make a long story very short, this alternative approach begins with the "collapse" of the Kantian project and Hegel's subsequent "temporalizing" of reason, where "for the first time we have in philosophy the distinction between an eternal order and a rational order." 48

It seems to me Foucault's work clearly falls within this "alternative" approach of thoroughly temporalizing reason and indeed makes an important contribution to it. And to appreciate that contribution, I would suggest that we not shy away from linking it to the mode of temporalizing reason as begun by Hegel (and not treat Foucault merely as one version of subsequent temporalizing continental philosophy, as McCumber himself largely does $)^{49}$, though for Foucault, the rational order explicated takes on the forms of discursive orderings by way of things said (which Foucault theorized for a time as énoncés) and things done (which Foucault theorized in terms of relations of power and "governmentality"). But in suggesting this, I do not mean the temporalizing of reason Hegel develops in his Phenomenology of Spirit ${ }^{50}$ from which, as mentioned above, Foucault surely meant to distance himself (given its overrepresentation in French philosophy at the time); rather, I want to sketch out briefly the categorial ordering found in Hegel's Science of $\operatorname{Logic}^{51}$ as the more appropriate context, specifically the second division of that work, which Hegel calls the Subjective Logic, which articulates the Doctrine of the Concept. This follows upon the first division and the discussion of what Hegel calls the Objective Logic, which is itself made up of the Doctrine of Being and the Doctrine of Essence, which will

\footnotetext{
${ }^{46}$ Béatrice Han, Foucault's Critical Project: Between the Transcendental and the Historical (2002).

${ }^{47}$ John McCumber, Time and Philosophy: A History of Continental Thought (2011).

${ }^{48}$ McCumber, Time and Philosophy, p. 8

${ }^{49}$ Ibid., 313-330.

${ }^{50}$ G.W.F. Hegel, Phenomenology of Spirit, [1806] (1977). Though the continuing relevance of this text and Foucault is argued for nicely in Muldoon, "Foucault's Forgotten Hegelianism."

${ }^{51}$ G.W.F. Hegel, Science of Logic, [1812] (1969).
} 
not be our concern here. It is important to understand that, for Hegel, the Subjective Logic is not subjective because it is opposed to the objective but because, following Kant's Copernican revolution, objectivity needs explicitly to be determined in relation to subjectivity.

The Doctrine of the Concept is divided into three parts, the first devoted to the Concept as such, the second to Objectivity, and the third to the Idea. This makes sense, of course, because if we are going to move to a consideration of logic - understood as the systematic appreciation of the categories involved in the deployment of valid thinking - in its subjective mode (the Subjective Logic), then thinking logically explicitly engages concepts first (combining them into judgments, and then articulating them into arguments, or syllogisms: which are the divisions of this first part). But such "subjective" considerations cannot stand alone, obviously, given the contrast they pose to "objectivity" which a logical approach must then consider (and so Hegel moves to the second part). Similarly, however, these "objective" considerations cannot stand alone, and call for a logical consideration of how both subjective and objective considerations factor into logical thinking. ${ }^{52}$ This is the concern of the third part of the Subjective Logic, which Hegel calls the Idea, and it is this third part that is most relevant for appreciating Foucault's philosophical contribution, and specifically the second section that deals with Idea of cognition. Or so I would suggest.

This is because it is here that rational ordering can be most clearly seen as temporalizing itself (determining itself), and it does this through theoretical elaborations aimed at truth and practical realizations aimed at the good. It is important to understand that, for Hegel, the Idea captures the unification of subjectivity (or the concept) and objectivity. ${ }^{53}$ In the logical development, the Idea arises out of the limitations of treating Objectivity on its own terms, independently of the subjectivity of thinking (the Concept). The point of the Idea is to express their unity. This expression of the unity of subjectivity and objectivity has an immediate form: Hegel calls it Life (the first chapter of the Idea section) inasmuch as Life unifies the subjectivity of this life living with the objectivity of life being lived (understood conceptually as a self-determining determinacy) but of course, simply as Life, ${ }^{54}$

\footnotetext{
${ }^{52}$ I think it is worth noting, simply because so many fault Hegel's philosophy for being "teleological," especially as it relates to history, that the category of teleology is actually treated here (it is also treated in the Doctrine of Essence, for distinct reasons I won't address here) as marking the transition to the Idea, simply because "objectivity" treated on its own does not yield the purposiveness that arises in thinking it through. That is, if thinking through external relations (as in "mechanism") or relations of affinity (as in "chemism," which together with "mechanism" constitute the first two chapters on the section dealing with "objectivity") are forms of valid thinking, they remain limited insofar as they exclude the question of purpose that is nevertheless raised in thinking these relations: to what purpose do these indifferent relations correspond? Only a subjective response to this question is possible, and thus objectivity needs once again to confront subjectivity. This is what the next section of the Logic addresses through the Idea. Thus, to accuse Hegel's philosophy as being marred with a kind of "finalism" is not to appreciate the way he works out these notions in his logical treatment of them.

${ }^{53}$ My discussion here follows Richard Dien Winfield, Hegel's Science of Logic: A Critical Rethinking in Thirty Lectures (2012).

${ }^{54}$ Additional support for situating Foucault's philosophy within the parameters suggested can be found in Foucault, Aesthetics, Method, and Epistemology, 475 where he explicates Canguilhem's discussion of "life" as concept (or rather the concept in life) in order to distinguish it from the phenomenological emphasis on
} 
it does so "unknowingly" or "unthinkingly" (on its own terms, it is merely a striving to maintain its unity as both this life and life itself). This is why the Idea of cognition follows Life, because it adds to its self-sustaining (i.e. self-determining) character the effort to know itself (as Hegel puts it, in the first instance it is an "urge" to truth) ${ }^{55}$ as the unification of subjectivity and objectivity. The Idea of cognition does this both theoretically and practically. In theoretical cognition, subjectivity unifies subjectivity and objectivity by modifying itself (as conceptual determination) to conform to truth as objectively determined. Whereas, in practical cognition, the unification of subjectivity and objectivity requires that objectivity be modified to conform to truth as subjectively determined (as what ought to be). As Winfield puts it:

Both theoretical and practical cognition, that is, both theory and practice (understood as distinct, one-sided endeavors), involve processes for unifying subjectivity and objectivity. Their processes thus involve the Idea or truth. In theorizing, the unifying process takes place in the conceptualizing, with given objectivity providing the standard to which theory must conform. In practice, the unifying process takes place in action that will alter objectivity to make it true, to make it what it ought to be. The good, what ought to be, here counts as true objectivity, not the realization of a merely arbitrary end. For practical cognition, objectivity as it is immediately given is not truthful, is not what it ought to be. Immediate objectivity therefore needs to be made truthful, to conform to subjectivity, to realize the good. Here, in effect, truth resides in subjectivity, which provides the measure for altering objectivity. The modification here takes place not in conceptual determination but in objectivity in accord with what is in subjectivity..$^{56}$

It is within these twin processes of cognition that I think we can best appreciate Foucault's philosophical contribution inasmuch as what I have been calling his distinct sensibility is very keen to their one-sidedness even in, or perhaps I should say as a function of, their "urge to truth." This "urge to truth" for Foucault was sometimes treated as a "will to

\footnotetext{
"lived experience," that is, "the concept insofar as it is one of the modes of that information which every living being takes from its environment and by which conversely it structures its environment. The fact that man lives in a conceptually structured environment does not prove that he has turned away from life, or that a historical drama has separated him from it - just that he lives in a certain way, that he has a relationship with his environment such that he has no set point of view toward it, that he is mobile on an undefined or rather broadly defined territory, that he has to move around in order to gather information, that he has to move things relative to one another in order to make them useful. Forming concepts is a way of living and not a way of killing life; it is a way to live in a relative mobility and not a way to immobilize life; it is to show, among those billions of living beings that inform their environment and inform themselves on the basis of it, an innovation that can be judged as one likes, tiny or substantial: a very special type of information." I think it is perfectly reasonable to read this account of the importance of the concept of life in life as an expression of its immediacy as Idea, in Hegel's sense. Transparency in Postwar France does an excellent job of situating the significance and place of Canguilhem's work in Postwar France.

${ }^{55}$ Hegel, Science of Logic, 783.

${ }^{56}$ Winfield, Hegel's Science of Logic, 333. In Hegel's systematic approach, the one-sidedness of each of these unifying processes of theoretical and practical cognition point to their unification in the Absolute Idea, the Idea that closes the Logic and self-determined determinate thinking can now turn to the "real" as Nature and Spirit.
} 
truth" that conceals from itself the conditions of its enunciation ${ }^{57}$ or again as "games of truth." 58 This last expression is probably the most interesting for seeing how Foucault's work situates itself within (and against) the Idea of cognition.

In the entry for the Dictionnaire des philosophes penned by "Maurice Florence," although nominally placing Foucault's philosophy in the "critical tradition of Kant," 59 it is characterized explicitly as a critical history of thought understood as "an analysis of the conditions under which certain relations of subject to object are formed or modified, insofar as those relations constitute a possible knowledge [savoir]." 60 This places his "analysis" squarely within the logical space of the Idea of cognition, in my view. That is, his concern with the conditions of knowledge is not a transcendental one concerned with the limits of its conditions of possibility, but an historical one, a concern with analyzing the actual determination of "knowledge" through the processes of cognition aimed at truth as these deploy themselves within and between the constitution of subjectivity and objectivity, or what "Florence" calls "subjectivation" and "objectivation." He continues:

It is not a matter of defining the formal conditions of a relationship to the object; nor is it a matter of isolating the empirical conditions that may, at a given moment, have enabled the subject in general to become acquainted with an object already given in reality. The problem is to determine what the subject must be, to what condition he is subject, what status he must have, what position he must occupy in reality or in the imaginary, in order to become a legitimate subject of this or that type of knowledge [connaissance]. In short, it is a matter of determining its mode of "subjectivation," for the latter is obviously not the same, according to whether the knowledge involved has the form of exegesis of a sacred text, a natural history observation, or the analysis of a mental patient's behavior. But it is also and at the same time a question of determining under what conditions something can become an object for a possible knowledge [connaissance], how it may have been problematized as an object to be known, to what selective procedure [procédure de découpage] it may have been subjected, the part of it that is regarded as pertinent. So it is a matter of determining its mode of objectivation, which is not the same either, depending on the type of knowledge [savoir] that is involved. ${ }^{61}$

Placing Foucault's philosophical concern here within the Idea of cognition allows us to appreciate the manner in which he explores the difference between knowledge and truth within the immanence of historical development as self-determination, the actual temporalized work of thought unifying subjectivity and objectivity. And Foucault's work is especially helpful in appreciating how this work of unification, through the "mutual development" and "interconnection" of modes of objectivation and subjectivation that count as knowledge in distinct times, issue into distinctively determining "games of truth." 62 Thus, the distinction between knowledge and truth is maintained in a way that does not place

\footnotetext{
${ }^{57}$ Michel Foucault, Archaeology of Knowledge, 218.

${ }^{58}$ Michel Foucault, Aesthetics, Method, and Epistemology, 460.

${ }^{59}$ Ibid., 459. Interestingly, this initial sentence, we are told, was actually written by F. Ewald.

${ }^{60}$ Ibid.

${ }^{61}$ Ibid., 459-460.

62 Ibid., 460.
} 
truth outside of the history of self-determination (as this is evidenced in the archive and in the struggles of the present, history as having been lived and cognized, and history as it is being lived and cognized). It is a thoroughly temporalized approach to the determination of truth.

But Foucault's work is also philosophically interesting in a more specific sense, and this brings us back to his distinct sensibility. As he continues this useful summary of his own assessment of his philosophical contribution, he notes that his questions were not posed "concerning just any game of truth, but concerning only those in which the subject himself is posited as an object of possible knowledge: What are the processes of subjectivation and objectivation that make it possible for the subject qua subject to become an object of knowledge [connaissance], as a subject?"63 How are we to account for this specific focus? Insofar as it is reasonable to attempt to do so for any given philosopher, ${ }^{64} \mathrm{I}$ have been suggesting that it is Foucault's discovery of the archive between the publication of his two "first" books. The first was a commissioned work that took up mental illness in a largely one-sided way as an "object" of theoretical cognition. ${ }^{65}$ The second eschews this "object" (mental illness) and instead embarks upon an archival exploration of a history of madness, where both subject and object come into the play of the workings of a "possible knowledge." And as I mentioned earlier, Foucault himself saw these historiographical explorations as not principally about pursuing a "knowledge" of the past (and thus not the work of an historian), that is, as not merely the one-sided activity of theoretical cognition, but also as a practical cognition aimed at transformation (and thus not the work of a theoretician), which we can now put in the terms of Idea of cognition, the transformation of the merely given "objectivity," in this case, the relation between madness and reason. And this preoccupation with the modes of objectivation and subjectivation animates Foucault's work throughout his career as his sensibility plumbs the archive, unsettling our understanding of delinquency, revolt, ${ }^{66}$ the abnormal, ${ }^{67}$ sexuality, forms of governmentality ${ }^{68}$ and relations to self. ${ }^{69}$

\footnotetext{
${ }^{63}$ Ibid.

${ }^{64}$ I am thinking here of Richard Dien Winfield's remark that: "Like Socrates, we must admit that any philosophy's quest for wisdom can be guided by but two things: recognition of our own ignorance and an opined understanding that there is a difference in meaning between opinion and truth. There can be no other rational grounds for taking up philosophy, since any appeal to guiding reasons would presuppose prior knowledge, signifying that philosophizing had already begun. All that can coherently urge us forward are divine voices, feelings of wonder, or some such name for an ignorant arbitrariness that leaves utterly undetermined what will follow." Overcoming Foundations: Studies in Systematic Philosophy (1989), 130.

65 The theories appealed to being "an unstable combination of Heideggerian existential anthropology and Marxist social history" (from the Forward written by Hubert Dreyfus, in Foucault, Mental Illness and Psychology, viii). I say "largely" because Foucault's biographers tell us about Foucault's own personal struggles throughout this time.

${ }^{66}$ Michel Foucault, The Punitive Society: Lectures at the Collège de France, 1972-1973 (2015).

${ }^{67}$ Michel Foucault, Abnormal: Lectures at the Collège de France, 1974-1975 (2003).

${ }^{68}$ Michel Foucault, Security, Territory, Population: Lectures at the Collège de France, 1977-1978 (2009).

${ }^{69}$ Michel Foucault, The Hermeneutics of the Subject: Lectures at the Collège de France, 1982-1982 (2005) and Michel Foucault, Subjectivity and Truth: Lectures at the Collège de France, 1980-1981 (2017).
}

Foucault Studies, No. 25, 103-119. 
Foucault's references to Kant are always interesting, to be sure, nowhere more so than in "What is Enlightenment?"70 But even in that text, it seems to me that what he is doing has less to do with Kant's critical project of limiting knowledge by articulating its conditions than exploring how the theoretical and practical cognitive practices establishing knowledge are unsettled when confronted with their own archive. Or, as Foucault puts it in that text: "if the Kantian question was that of knowing what limits knowledge has to renounce transgressing, it seems to me that the critical question today has to be turned back into a positive one: in what is given to us as universal, necessary, obligatory, what place is occupied by whatever is singular, contingent and the product of arbitrary constraints? The point, in brief, is to transform the critique conducted in the form of necessary limitation into a practical critique that takes the form of a possible transgression."71 This transformation of critique seems to me to be implicit in the work of Hegel's Idea of cognition as it struggles theoretically and practically to know the truth. Foucault, through his distinct sensibility, reminds us that such work and the struggles it entails do not issue into a simple given, but rather that they call us to a "permanent critique of ourselves."72

\section{Conclusion}

What I have suggested, then, is that it is within his working of the archive that Foucault discovered and engaged the "alternative" philosophy of temporalizing the unification of subjectivity and objectivity that Hegel calls truth. This is the lasting philosophical significance of his work, his engagement with the manner in which the twin processes deploy themselves as cognition, all the while refusing to cede that unification to the conception of a timeless truth. To be sure, Foucault himself likened some of his concerns to Kant, but his histories have little of the transcendental to them, in structure or in spirit. If there is something of Kant, it is to be found in an attentiveness to the relation between the sensibility and the understanding. But here too, there is something distinct about Foucault's sensibility, its receptivity. Alive within the archive (and powerfully evoked in "Lives of Infamous Men" where he allowed himself to be "guided by nothing more substantial than my taste, my pleasure, an emotion, laughter, surprise, a certain dread, or some other feeling whose intensity I might have trouble justifying, now that the first moment of discovery has passed," 73 I have suggested it is distinctly inflected, keen to the play of possibility, necessity, and contingency not yet taken up within and through the cognitive work of the understanding as this manifests itself in various deployments of the will to know. Herein lies the force of his writings, their continuing philosophical resonance. Through his philosophically engaged histories - his archival explorations of what has actually been "said" and "done" in the name of knowing ourselves as "subjects," as shaped by the twin one-

\footnotetext{
${ }^{70}$ Michel Foucault, “What is Enlightenment?" in The Foucault Reader (1984).

${ }^{71}$ Ibid., p. 45.

72 Ibid., p. 43.

${ }^{73}$ Foucault, Power, 157.
} 
sidedness of theoretical and practical cognition - he keeps open the possibility of transformation and a truth other than knowledge of the merely given or the merely constructed, and thereby reconnects us to the difficult space of our freedom.

\section{References}

Badiou, Alain, The Adventure of French Philosophy. London : Verso, 2012.

Baugh, Bruce, French Hegel: From Surrealism to Postmodernism, London: Routledge, 2003.

Boquet, Damien, Blaise Dufal, and Pauline Labey, eds. Une histoire au présent: Les historiens et Michel Foucault. Paris: CNRS, 2013.

Collingwood, R.G., An Essay on Philosophical Method. Oxford: Clarendon Press, 1936.

Connolly, William E, "Beyond Good and Evil: The Ethical Sensibility of Michel Foucault," Political Theory 21 :3 (1993), 367.

Derrida, Jacques, Archive Fever: A Freudian Impression. Chicago: University of Chicago Press, 1996.

Eliassen, Knut Ove, "The Archives of Michel Foucault » in The Archive in Motion : New Conceptions of the Archive in Contemporary Thought, ed. Eivind Rossaak. Oslo: Novus Press, 2010.

Eribon, Didier, Michel Foucault. Cambridge: Harvard University Press, 1991.

Falzon, Christopher and Timothy O'Leary, "Introduction: Foucault's Philosophy," Foucault and Philosophy, eds. Timothy O'Leary and Christopher Falzon, 1-16. Oxford: Wiley-Blackwell, 2010.

Farge, Arlette, 'Travailler avec Michel Foucault” Le débat, 41:4 (1986), 164-167.

Farge, Arlette, "Écrire l'histoire", Hypothèse 7:1 (2004), 317-318.

Farge, Arlette, The Allure of the Archives. New Haven: Yale University Press, 2013.

Farge, Arlette and Michel Foucault, Disorderly Families: Infamous Letters from the Bastille Archives, ed Nancy Luxon. Minneapolis: University of Minnesota Press, 2016.

Fillion, Réal, "Foucault after Hyppolite: Toward an A-theistic Theodicy" The Southern Journal of Philosophy 43:1 (2005), 79-93.

Foucault, Michel, Hisitoire de la folie. Paris: Gallimard, 1972.

Foucault, Michel, The Archaeology of Knowledge and the Discourse on Language. New York: Pantheon Books, 1972.

Foucault, Michel, Herculine Barbin dite Alexina B. Paris: Gallimard, 1978.

Foucault, Michel, Herculine Barbin: Being the Recently Discovered Memoirs of a Nineteenth Century French Hermaphrodite, New York: Vintage Books, 1980.

Foucault, Michel, "What is Enlightenment?" in The Foucault Reader, ed. Paul Rabinow, 32-50. New York: Pantheon, 1984

Foucault, Michel, Mental Illness and Psychology. Berkley: University of California Press, 1987.

Foucault, Michel, “Des espaces autres” Dits et écrits IV. Paris: Gallimard, 1994.

Foucault, Michel, "Foucault," in Aesthetics, Method, and Epistemology: Essential Works of Foucault 1954-1984, Volume 2, ed. James D. Faubion, 459 -463. New York: New Press, 1998.

Foucault, Michel, Power: Essential Works of Foucault" [1954-1984], Volume 3. New York: The New Press, 2000.

Foucault, Michel, Abnormal: Lectures at the Collège de France [1974-1975]. New York: Picador, 2003. 
Foucault, Michel, The Hermeneutics of the Subject: Lecture at the Collège de France [1982-1982]. London: Palgrave Macmillan, 2005.

Foucault, Michel, Security, Territory, Population: Lecture at the Collège de France [1977-1978]. New York: Picador, 2009.

Foucault, Michel, The Punitive Society: Lectures at the Collège de France [1972-1973]. London: Palgrave Macmillan, 2015.

Foucault, Michel, Subjectivity and Truth: Lectures at the Collège de France [1980-1981]. London: Palgrave Macmillan, 2017.

Foucault, Michel, Les aveux de la chair. Paris: Gallimard, 2018.

Geroulanos, Stefanos, Transparency in Postwar France: A Critical History of the Present. Stanford: Stanford University Press, 2017.

Han, Béatrice, Foucault's Critical Project: Between the Transcendental and the Historical, Stanford: Stanford University Press, 2002.

Han-Pile, Béatrice, "Is early Foucault a Historian? History, history and the analytic of finitude » Philosophy E Social Criticism, 31: 5-6 (2005), 585-608.

Hegel, G.W.F., Phenomenology of Spirit. Oxford: Oxford University Press, 1977.

Hegel, G.W.F., Science of Logic. New York: Humanities Press, 1969.

Kelm, Holden, "With Hegel Against Hegel?: Strategic and Methodological Implications of Foucault's Anti-Hegelianism" Hegel-Jahrbuch (2015), 323-328.

Lawlor, Leonard, Thinking Through French Philosophy: The Being of the Question. Bloomington: Indiana University Press, 2003.

Le Goff, Jacques, and Pierre Nora, Faire de l'histoire. Paris: Gallimard, 1974.

Macey, David, The Lives of Michel Foucault. New York: Vintage Books, 1993.

McCumber, John, Time and Philosophy: A History of Continental Thought, Durham: Acumen, 2011.

Megill, Allen, "The Reception of Foucault by Historians" Journal of the History of Ideas 48:1 (1987), 117-141.

Muldoon, James, "Foucault's Forgotten Hegelianism" Parrhesia 21 (2014), 102-112.

Nora, Pierre, (ed.) Essais d'ego-histoire. Paris: Gallimard, 1987.

Perrot, Michelle (ed.), L'impossible prison: Recherches sur le système pénitentiaire au XIXe siècle. Paris: Seuil, 1980.

Veyne, Paul «Foucault Revolutionizes History, » in Foucault and his Interlocutors, ed. Arnold Davidson, 146-182. Chicago: University of Chicago Press, 1997.

Winfield, Richard Dien, Overcoming Foundations: Studies in Systematic Philosophy. New York: Columbia University Press, 1989.

Winfield, Richard Dien, Hegel's Science of Logic: A Critical Rethinking in Thirty Lectures. Lanham: Rowman \& Littlefield Publishers, 2012.

Author info

Réal Fillion, $\mathrm{PhD}$ Associate Professor Department of Philosophy University of Sudbury

Canada rfillion@usudbury.ca 